\title{
DESCRIPTION OF A MODEL FOR LESSON PLANNING ON PEACE EDUCATION IN TEACHER TRAINING
}

\author{
HASAN COŞKUN \\ Çankırı Karatekin University, Faculty of Letters, \\ Department of Education, Fatih Mahallesi, \\ Uluyazı Kampüsü Ring Yolu, 18100 Çankırı, Turkey \\ E-mail address: hcoskun1952@gmail.com \\ hasancoskun@karatekin.edu.tr
}

\begin{abstract}
Aim. The aim of the research is to describe the model for lesson planning on peace education in teacher training. The used resources are aimed at filling the shortcomings in peace education and improving the value of the materials available to teachers. In preparing the lesson, a teacher will either use the models available to him/her or develop his/her own models in time.

Concept and Methods. This study was conducted by qualitative research. The document research technique was used in the study (Yıldırım, \& Şimşek, 2008, pp. 187-193). For the last three years, I have been working on the model related specifically to peace education as part of the project of the Turkish research institute called TÜBITTAK.

Result and Conclusion. This model was presented during the academic year 2017/2018 at several conferences in Turkish, German and English. In this article, the topic of "Tolerance Towards Different Cultures" was chosen to define the practical part of the lesson preparation because this topic is of particular interest to many countries, due to migration. The refugees experience certain problems in the areas of language, culture, employment, social acceptance and prejudice. In order to minimize these problems, various measures are taken in the field of education.

Originality. The participants showed great interest in the designing of the daily lesson planning and the implementation of this design in the teaching of peace in the training of the teachers. The studies in this field should be supported in order to increase peace education.
\end{abstract}

Key words: Migration, cultural diversity, tolerance, peace education, lesson planning

\section{INTRODUCTION}

To integrate the refugees into society, it is crucial that they should learn the official language, should discover closely the culture of the society they live in, should get the necessary education, and must have a profession (Grosser, 2017, 
pp. 123-152). In this respect, the institutions of education must play a serious role. In the institutions of education, the motivation of the teachers and their educational background play an important role. Especially peace education aims to help the natives live with the refugees peacefully. Generally speaking, the necessity of peace education can be put forward as indicated below.

1. War conditions prevail in several countries.

2. There are currently more than 65 million people in the world forced to leave their home countries.

3. Migration causes a number of problems in areas such as society, economics, politics, employment, education.

4. Today's students are the citizens and politicians of tomorrow who will struggle for world peace instead of fighting wars.

5. Man needs security, peace, education and acceptance. The possibility to accomplish this is through peace education.

6. Certain clashes can come into being between cultures, religions and sects.

The teachers who want to contribute to provide the tranquility and the continuation in society peace should give answers to the following question while preparing their lesson plans:

1. Why is peace education important?

2. How should peace education be integrated into, in general, educational system and, specifically, curriculum?

3. Should Peace Education be a course?

4. Should Peace Education be included in all courses with an interdisciplinary point of view?

There are four questions to answer:

The answer to the first question: There are currently more than 65 million people in the world forced to leave their home countries. War conditions prevail in several countries. Man needs security, peace and acceptance. The possibility to accomplish this is through peace education. In short, today's students are the citizens and politicians of tomorrow who will fight for world peace instead of fighting wars.

The answer to the second question: There are, of course, a number of ways how we could integrate peace education into the education system and curricula. I think teacher education plays a big role in peace education. Peace education can be dealt with in interdisciplinary events, in regular events, in congresses and in workshops.

The answer to the third question: In my opinion, it is not realistic to introduce peace education as a course. Often new topics are proposed as new courses. The time in educational institutions would not be sufficient for all subjects as independent courses. The education should be contemporary. The goal of contemporary education is peace.

The answer to the fourth question:

The answer is definitely yes. In this article, I would like to discuss the topic of peace education in teacher education. I would like to introduce a model that I developed for the planning of lessons. 


\section{METHOD}

As stated in the abstract, this study was conducted by qualitative research method. The document research technique was used in the study (Yildirım, \& Şimşek, 2008, pp. 187-193). I first developed a draft for class preparation in collaboration with experts. Based on this draft, 250 students each made a lesson plan for a topic in the field of peace education. Ten students presented their plans. The participants and the author made suggestions for improvement. Then the students formed groups of five. Each group checked the prepared five plans and selected the best one. Each group worked on the selected plan and introduced it to the class. After the presentation, each group made the necessary improvements based on the criticisms and suggestions. A commission of students re-inspected the 50 plans under the direction of the author. The author selected 12 copies of 50 plans for a book publication. After intensive editing, these 12 copies were published. This book was presented at a meeting of Turkish and British participants. Based on the criticism and suggestions of the participants from England and Turkey, this teaching model was developed. This model consists of 13 steps. I will go through each step briefly.

\section{GENERAL INFORMATION}

The sample lesson plan should be aimed at a specific target group. Therefore, general information such as the education institution, branch of the lesson, the subject and the duration should be identified. The prepared sample lesson plan should be aimed at a target group. Therefore, the type of school, the name of the lesson, the subject and the duration should be stated.

Target Group: Students of courses German for Communication

Name of the lesson: German as a foreign language

Topic: Different cultures and tolerance

Duration: 80 minutes (2 class hours)

\section{RATIONALE OF THE LESSON}

The selection of a topic is justified by the teacher (Meyer, 1978, p. 152). A sample lesson plan may either be a subject contained in the education and teaching program approved by the Ministry of Education and, or a subject to be proposed by the teacher candidates. If the subject selected is included in the education program approved by the Department of Education and Teaching of the Ministry of Education, the justification for the subject is already specified by teacher candidates and teachers-on-the-job developing the education and teaching program. If the subject is proposed by the teacher candidates or a 
teacher who is implementing the subject reasons, why the subject is selected and why the subject has to be discussed in the class, a justification written in approximately 200 words must be given. When writing the justification the contribution of the proposed subject to the individual, the society and the subject in question should be emphasized. If millions of people are not able to live happily in their own country and are forced to leave their countries, nothing is more meaningful and humanitarian than teaching tolerance in the educational institutions (DPA, 2016, p. 3).

The notion of tolerance comes from the French word (tolerance). Püsküllüoğlu (1995, p. 760) explains the model of tolerance in the following manner: "(1) Tolerance is the condition when things may seem contrary to you but to accept them with understanding. (2) In philosophy, although the thoughts and opinions of an individual may be in conflict with yours, you should not to be disturbed and not react to the individual who expresses his/her thoughts and opinions and not to show any reaction on the validity of what is expressed." Bakırcioğlu (2016, p. 759) states his opinion on the aforementioned model in the following manner: "Tolerance is to accept, with understanding, different thoughts, attitudes and behavior which are considered to be wrong by you and to grant to others the rights bestowed on yourself."

Tolerance means to accept differences or to leave others alone and to listen patiently to their opinions which may be contrary to your or the views of the majority in their actions or judgments without holding sides. It means to let them have their say and to ignore their views. Sometimes in social relations one party unknowingly or intentionally may create a situation which is disturbing to the others and the ability of the other party to ignore this situation or not reply to the situation and show understanding is a virtue. In Sufism Mevlana is shown as an example of tolerance (Wikipedia, 17.04.2017).

Tolerance makes it easier for people coming from different cultures to live together. Therefore, one of the primary purposes of the Turkish education system should be to enable children to become tolerant and to become aware of different cultures without discrimination at a young age. One of the purposes of the Turkish education system is for children to become universal beings. Therefore, combining different cultures in the daily lesson plan will serve this purpose. In drafting this activity, the children trying to approach those people with different understanding was taken as the basis. Additionally, the basic objectives of education should be to teach children to have empathy. In order to achieve these goals tolerance should be taught at educational institutions. With the announcement made by Donald Trump, the President of the United States of America, on 7 December 2017 that "he has recognized Jerusalem as the capital of Israel", the model of peace is even more important today in the world (Taştekin, 2017). 


\section{THE OBJECTIVES OF THE LESSON}

One of the important topics in the preparation of the daily lesson programs is the writing of the objectives of the lesson because all the activities performed should be aimed at achieving the envisioned objectives. It is possible to talk about various schools in Turkey. For a long time in Turkey, discussions were made on objectives and the conversion of the objectives into behavior. in universities and educational institutions. Today the model of gains is being discussed as well. Because objectives into behavior require a lot of detailed work, it takes a lot of the teachers' time. In this present work, I used the objective writing matrix, widely used in Germany.

In planning daily lessons, the objectives of each activity (what the student will gain), should be identified beforehand (Demir, 2010, pp. 96-100). The other works related with the lesson planning should be shaped according to the envisioned targets. The objectives should be short, brief and easily understandable. The candidate teachers are expected to be knowledgeable in preparing objectives and are expected to write at least 5 targets in connection with the lessons target writing. As far as possible the objectives should cover cognitive, affective and psycho-motor domains (Coşkun, 2015, p. 62). Below are given the objectives for the sample lesson plans prepared in connection with "Different Cultures and Tolerance".

One of the most important components of a lesson plan is the objectives because all the work to be performed in connection with the activities should fulfill the envisioned targets. Dağyeli Verlag (Dağyeli Publishing House) recommends the use of a certain model that is frequently used in the German education system. In the lesson, the objectives for each activity should be specified (Demir, 2010, pp. 96-100). The activities related with the lesson should be shaped according to the envisioned objectives. The objectives should be brief, specific and understandable.

When preparing the lesson plan, the teachers are asked to write a short paragraph about the topic that they would like to cover in the lesson and state at least five objectives related with the sample lesson plan. As far as possible, the objectives should cover the cognitive, affective, and psycho-motor domains (Coşkun, 2015, p. 62). Below are some sample objectives taken from a lesson plan.

The students who take part in this lesson will:

- remember their experience with different cultures.

- improve their knowledge about different cultures.

- learn to tolerate those who are different from themselves.

- get to meet individuals coming from different cultures and learn to be tolerant towards them.

- comprehend the importance of living in peace and harmony with themselves and society.

- make recommendations to prevent clashes starting from their neighborhood and around the world for peace to prevail.

- exert efforts for the realization of the recommendations they made for peace. 


\section{EXPLANATION OF THE KEYWORD AND THE 24 WORDS USED IN THE LESSON}

I have designed all the work that I have performed up to now on teaching a foreign language based on the Nine Stone Game (Coşkun, 1996, pp. 14-34). One keyword and 24 words are used in this unique game I have prepared to teach the subject and practice pages. The keyword should symbolize the subject selected and the 24 words should be directly related with the subject. Some information should be given to the teachers and teacher candidates on the selection of the words. Words should be easy to understand so that some pictures can be drawn on them. The selected 24 words should be placed in alphabetical order in the language the target groups know best (In this sample lesson plan, 24 words were written in alphabetical order according to the Turkish alphabet.) Then, the corresponding words of the other languages should be written in the tri-lingual list. It is possible to increase the number of the languages in the list according to the needs.

As a result of the developments in the world it can be seen that the number of lessons given in foreign languages has increased. It is assumed that Turkey will be affected even more by these developments in the World. The students in Turkey should observe these developments and adjust themselves to the developments in the world. The teacher candidates can benefit from educational technology and the capabilities in the universities in preparing their lessons in three languages at least at the model level. In respect to the development of the linguistic skills, preparation of tri-lingual lists is one of the important steps. Given below is the key word selected for this study. The chart prepared for the key word calls for five sentences written in Turkish, German, and English for the said drawing. After the key word, the given tri-lingual list is inserted. In the later stage it is recommended for the students to write sentences with the words contained in the list and then to write texts from the sentences.

Table 1. Flash card for "tolerance"

The keyword and the 24 words in the lesson Flaş Kart / Lernkarte / Flash Card

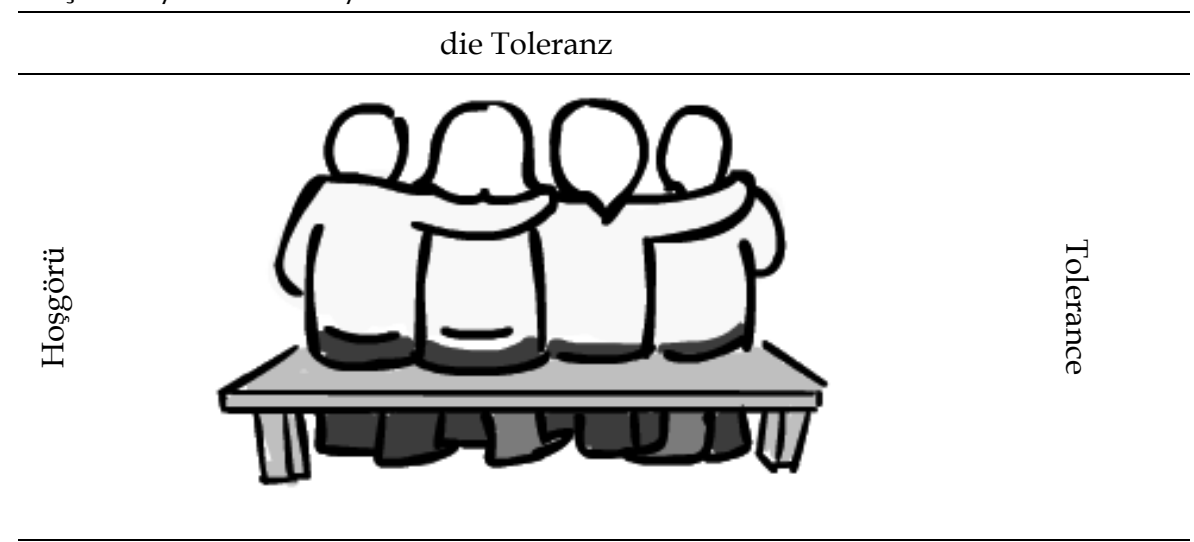




\section{$\mathrm{OO}$}

Bu resim ile ilgili 5 Türkçe, Almanca ve İngilizce cümle yazınız.

Schreiben Sie über dieses Bild 5 Sätze auf Türkisch, Deutsch und Englisch.

Write down 5 sentences about this picture in Turkish, German and English.

\begin{tabular}{|c|c|c|c|}
\hline No & Türkçe & Deutsch & English \\
\hline 01 & $\begin{array}{l}\text { Hoşgörü birliktelik } \\
\text { gerektirir. }\end{array}$ & $\begin{array}{l}\text { Toleranz erfordert } \\
\text { Einheit. }\end{array}$ & $\begin{array}{l}\text { Tolerance requires } \\
\text { unity. }\end{array}$ \\
\hline 02 & Barış mutluluk getirir. & Frieden bringt Glück. & $\begin{array}{l}\text { Peace brings } \\
\text { happiness. }\end{array}$ \\
\hline 03 & $\begin{array}{l}\text { Hoşgörü barışı, barış ise } \\
\text { sevgiyi getirir. }\end{array}$ & $\begin{array}{l}\text { Toleranz bringt Frieden, } \\
\text { Frieden bringt Liebe. }\end{array}$ & $\begin{array}{c}\text { Tolerance brings peace } \\
\text { while peace brings } \\
\text { love. }\end{array}$ \\
\hline 04 & $\begin{array}{l}\text { Barış ile birlikte daha } \\
\text { güvenilir bir toplum } \\
\text { oluşur. }\end{array}$ & $\begin{array}{l}\text { Mit dem Frieden } \\
\text { entsteht mehr Vertrauen } \\
\text { in der Gesellschaft. }\end{array}$ & $\begin{array}{l}\text { Together with peace } \\
\text { more confidence } \\
\text { develops in society. }\end{array}$ \\
\hline 05 & $\begin{array}{l}\text { Barış herkes için } \\
\text { gereklidir. }\end{array}$ & Frieden braucht jeder. & Everyone needs peace. \\
\hline
\end{tabular}

Source: Psychologytoday.com, retrieved July 26, 2017

Table 2. First group of words for tolerance

Sözcük Listesi / Wortliste / Word List / Höşgörü / die Toleranz/Tolerance (a)

\begin{tabular}{|c|c|c|c|c|}
\hline Nr. & Resim/Bild/Picture & Türkçe & Deutsch & English \\
\hline 01 & & barış & der Frieden & peace \\
\hline 02 & & birlik & die Gemeinschaft & unity \\
\hline 03 & & bölünmek & geteilt sein & division \\
\hline 04 & & çatışma & der Konflikt & conflict \\
\hline
\end{tabular}


Journal of Education Culture and Society No. 1_2018

\begin{tabular}{|c|c|c|c|c|}
\hline Nr. & Resim/Bild/Picture & Türkçe & Deutsch & English \\
\hline 05 & & çocuk & das Kind & child \\
\hline 06 & & din & die Religion & religion \\
\hline 07 & & düşmanlık & die Feindseligkeit & hostility \\
\hline 08 & & empati & die Empathie & empathy \\
\hline 09 & & farklılık & die Vielfalt & diversity \\
\hline 10 & & güven & das Vertrauen & trust \\
\hline 11 & & güvercin & die Taube & dove \\
\hline 12 & & göç & die Migration & migration \\
\hline
\end{tabular}

Source: Author.

Table 3. Second group of words for tolerance Sözcük Listesi / Wortliste / Word List / Hoşgörü / dieToleranz / Tolerance (b)

\begin{tabular}{ccccc}
\hline Nr. & Resim / Bild/Picture & Türkçe & Deutsch & English \\
& & & & \\
& & hassasiyet & die Sensibilität & sensibility
\end{tabular}




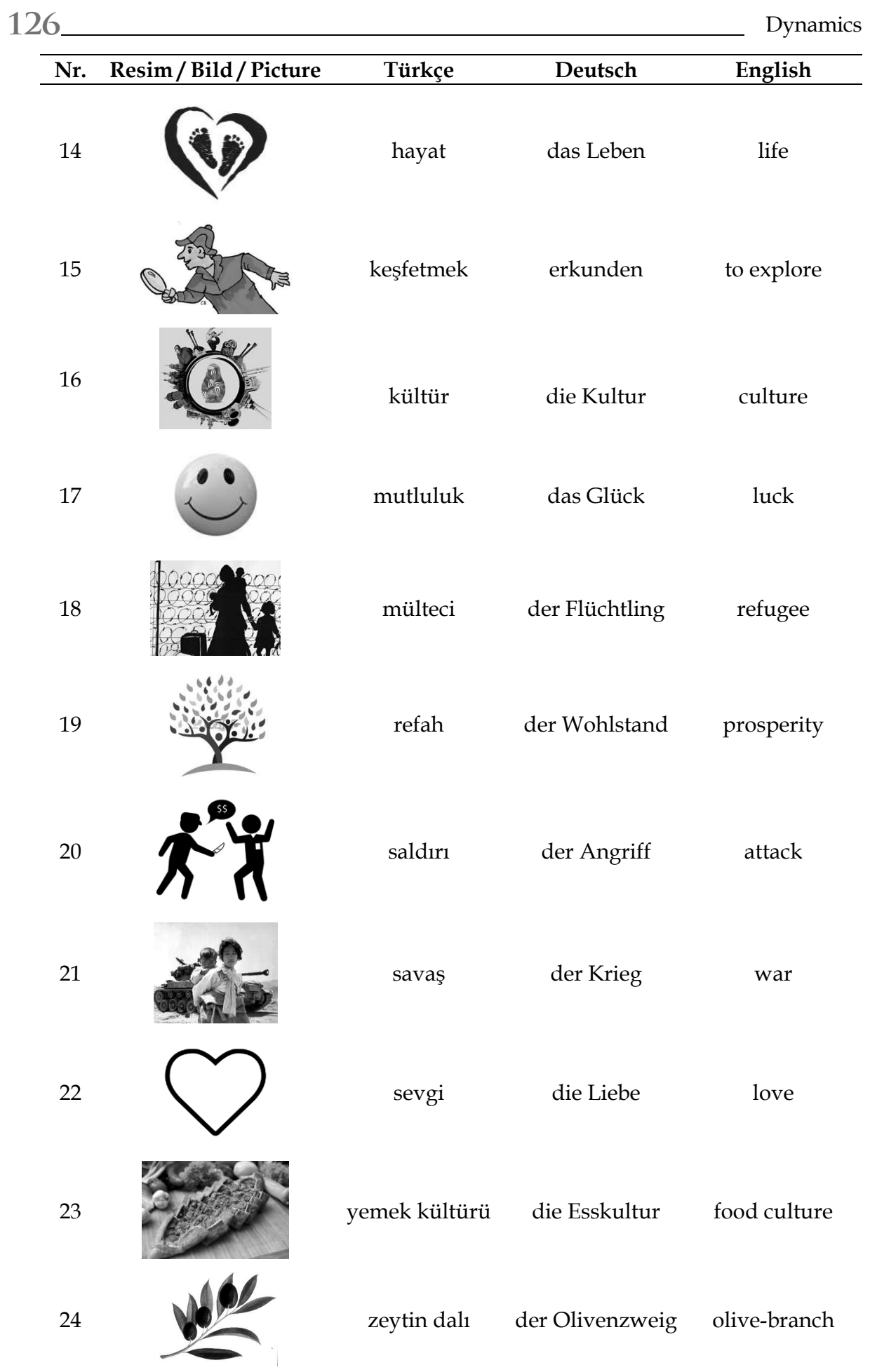

Source: Author. 


\section{DiALOGUE}

(Participants: Gözde Kerim, Derin, Paul, Barbara, Jörg)

Students will also be asked to write a dialogue and an essay of 200 words (5 paragraphs). In a dialogue that takes place among six persons, it is recommended that the key word and the 24 words listed below are used in a balanced manner. A sample list of words together with the key word, a dialogue, and a reading text are given below.

Table 4. Dialogues among participants

\begin{tabular}{|c|c|c|}
\hline No & Persons & Speech texts \\
\hline 01 & Kerim & There was news of another attack on the television. Did you see it? \\
\hline 02 & Derin & Yes, I saw it. Clashes occurred. People were leaving the area. \\
\hline 03 & Paul & I don't understand! What is the cause of this hostility? \\
\hline 04 & Jörg & Fearing war, the refugees have started to migrate to other countries. \\
\hline 05 & Barbara & This flow of migration primarily affects children and women. It is very sad. \\
\hline 06 & Kerim & $\begin{array}{l}\text { We are so divided now. There are some who do not feel sad for the death of } \\
\text { children and women. }\end{array}$ \\
\hline 07 & Derin & We have to be very sensitive to these issues. \\
\hline 08 & Paul & We need some empathy here. \\
\hline 09 & Gözde & $\begin{array}{l}\text { Do you think there is anything about their culture that the refugees can } \\
\text { contribute to us? }\end{array}$ \\
\hline 10 & Barbara & Hmm... We will meet new people from a different culture. \\
\hline 11 & Jörg & We will witness some new culinary culture. \\
\hline 12 & Derin & We will have the opportunity to learn about their religions and sects. \\
\hline 13 & Paul & We will meet new individuals. \\
\hline 14 & Jörg & We have a very optimistic view. What if they attack us? What happens then? \\
\hline 15 & Kerim & We need to trust them rather than be afraid of them. \\
\hline 16 & Gözde & For this purpose each of us should be his peace dove. \\
\hline 17 & Derin & I agree. If there is peace we will live happily. \\
\hline 18 & Paul & Yes, this is very important for a life full of love. \\
\hline 19 & Derin & $\begin{array}{l}\text { If there is love, respect, tolerance and peace in our country, our affluence } \\
\text { will increase. }\end{array}$ \\
\hline 20 & Kerim & Together we will develop our country even more. \\
\hline 21 & Derin & I absolutely agree. Fighting does not bring any good to anybody. \\
\hline 22 & Paul & Hostility will only divide us. \\
\hline 23 & Barbara & How about children and women? We must give them protection. \\
\hline 24 & Kerim & Yes, the refugee problem concerns the whole world. \\
\hline 25 & Paul & Refugees who migrate because of war need us very much. \\
\hline 26 & Jörg & We must treat them with tolerance. \\
\hline 27 & Kerim & We only gain hostility with clashes and war. \\
\hline 28 & Gözde & We need to embrace them with this in mind. \\
\hline 29 & Barbara & Yes, everybody trusts himself/herself. \\
\hline 30 & Derin & We all need to be ambassadors of peace. \\
\hline
\end{tabular}


Questions related to the dialogue

- What is empathy?

- Who is most affected by the flow of refugees?

- Which event is the most effective solution for the problems caused by different cultures?

- Whose name comes first in mysticism as an example of tolerance?

- How does being tolerant help in living with people coming from different cultures?

\section{Reading text}

In this model, a text comprised of approximately 200 words and 5 paragraphs on the subject envisioned should be written. In the text, attention should be paid to the use the keyword and the 24 words contained in the tri-lingual list in a balanced manner.

\section{DIFFERENT CULTURES AND TOLERANCE}

If the question "What is tolerance?" is asked, I am sure most people may express their thoughts and opinions. Tolerance is to listen to the opinions and thoughts, which may be totally contrary to yours, of the individual before you with compassion and without objection. Tolerance is taught to the children at first by the parents and relatives and then in school. At a very young age children should be taught that everybody is the same and equal regardless of their cultural differences, their language, religion, gender, nationality, and race.

The World we live in contains a huge variety. Perhaps this variety is what makes it beautiful. Sometimes these differences cause clashes, and people are forced to leave their homes. They call this "clash war." Some children are born right in the middle of a war. If we cannot identify with them we may lose our sense of humanity. Some accept those escaping from the war as refugees. In providing this assistance everything that is necessary for the comfort and order of society should be done. The sooner the society accepts refugees and treats them with compassion; the sooner peace will be achieved.

Every society has more than one culture. This is called cultural wealth. Culture is a heritage and is transferred from one generation to another. This heritage continuously develops. The food, clothes, and languages of every society may vary. The important thing is to be able to communicate with each other. To live is the right of every human being. The first right is the right to live. Religion also varies with every society. But all religions have one thing in common that says "Thou shall not kill". Killing is forbidden by religion because no religion tolerates the hurting of a living being by another in any way.

In my opinion a child is the most beautiful bond. The family teaches the child to have empathy at a very young age. The family, at the same time, gives the child a sense of trust. The sense of trust helps the child to develop his/her curiosity and ability to discover, rather than fear differences. 
Rather than creating division in the multi-cultural environment we live in, we should convert differences into opportunities. The world is enough for all of us. We should set aside our jealousies and clashes of interest and extend an olive branch to heal ill feelings. We should live life not with jealousy and anger but with respect, peace and love. This is not impossible to achieve: all we need is the will to do this.

\section{Questions related with the reading text}

- What is tolerance?

- Where do we first learn tolerance?

- Does each society have its unique culture?

- What do you call those people who flee war and take refuge in other countries?

- What is the basic human right?

\section{THE IMPORTANCE OF THE EDUCATIONAL GAME}

The teacher candidates are expected to write two paragraphs (approximately 100 words) about the importance of educational games. They can express their thoughts and participate in the activities actively. They can be aware of their friends' views because applied education is given so that the students can retain the lesson better. In addition, the participants learn that they should not interrupt the student who is talking during the game and should respect his/ her opinions.

Students learn to approach each other's opinions with tolerance through games. The peaceful environment achieved through educational games enables the students to express their opinions more freely. For this reason, educational games are important for the students to express themselves in the classroom and to mingle with their friends. For this reason the activity directors should select the educational game they will be using and if possible they should design and prepare the game themselves.

Through games the students will learn how their cultures are handed down from generation to generation. The students will learn the interaction of the cultures, the cultures in multi-lingual, multi-cultural and multi-faiths environments. The exchange of cultural information will help them realize differences and similarities between cultures. In this manner, the students will become familiar with customs and habits. The students will be curious about the cultures of other countries and will want to learn about them. They learn to respect the differences. This feeling of respect helps in the development of tolerance. They will relate this feeling of tolerance to different cultures and opinions. The students will learn to be tolerant to people different from them all their lives and realize that this is very important for the society to live in peace (Şahbenderoğlu, 2010). 


\section{RULES OF THE WORD DRAWING EDUCATIONAL GAME}

One of the important elements of the sample lesson plan is the rules of the educational game. Therefore, candidate teachers are requested to describe the rules of the game they will be using in the lesson in 15 items. Given below are the rules of the word drawing game.

Table 5. Rules of the word drawing educational game

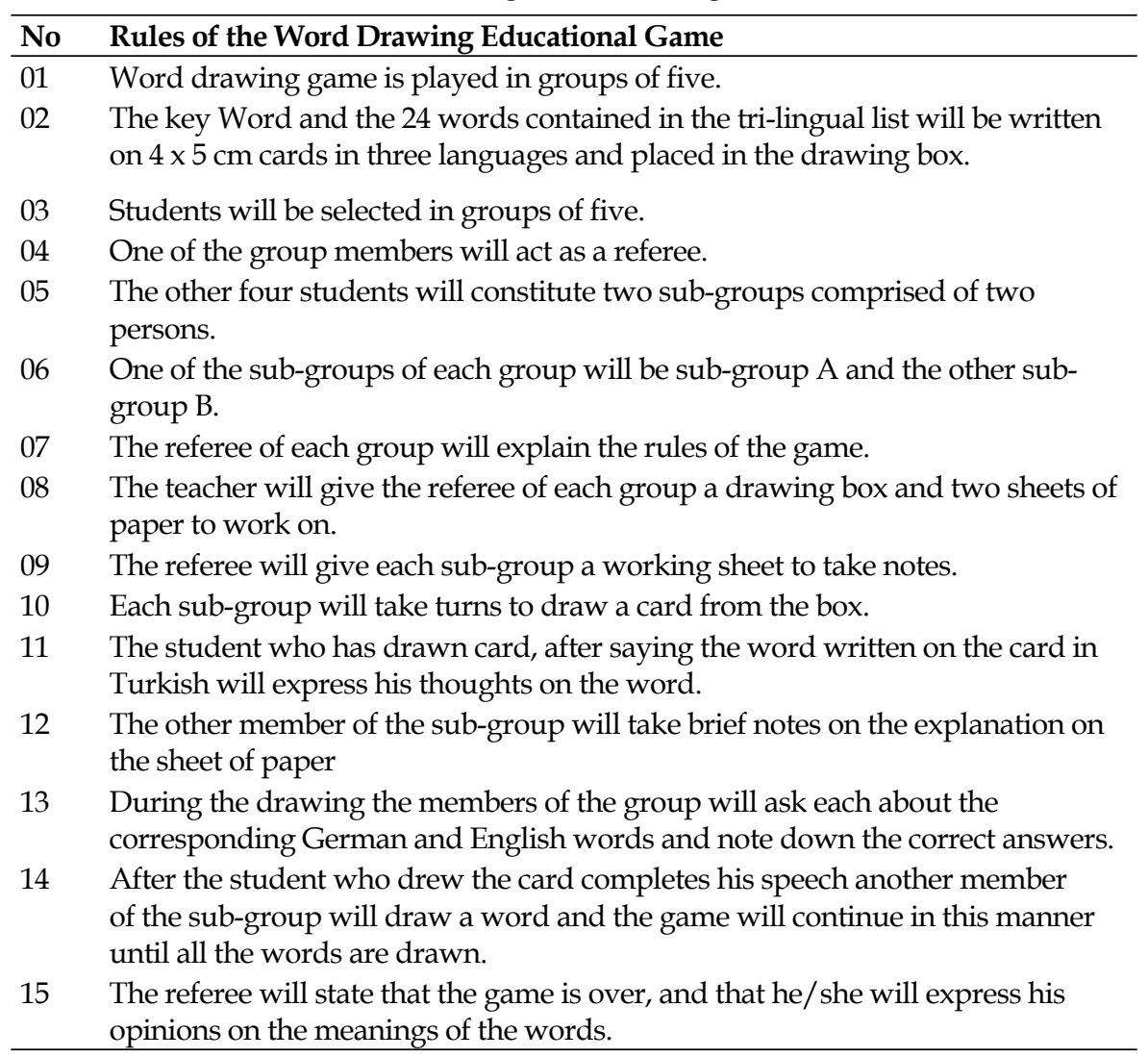

Explanation: Word drawing game may also be played by five persons on the table. The rules of this version shall be determined by the players.

\section{THE MATERIALS TO BE USED FOR THE EDUCATIONAL GAME}

The use of unique materials plays an important role in lessons. The teachers are requested to develop three dimensional materials and explain the materials in a text comprised of 200 words. It is recommended that they use pictures (images), drawings, charts etc. when necessary. 

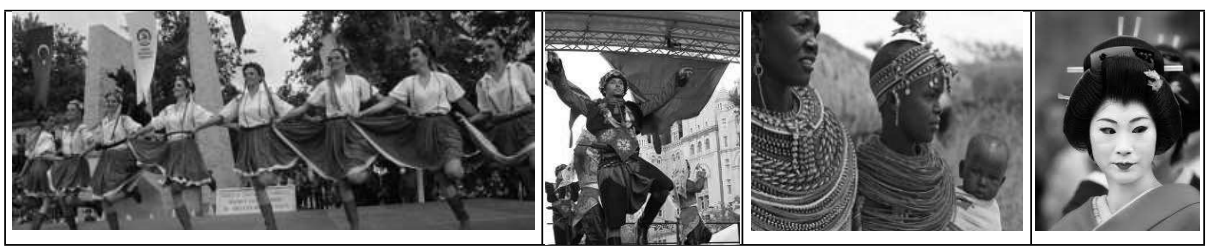

Image 1. Different cultures

Source:15th International Folk Dance Festival in Denizli, Retrieved, July 24, 2017.

Before beginning the educational game the teacher may show some pictures of different cultures with a projector on the wall and may ask for explanations of these images. Later, the teacher asks the students some questions in line with the questions outlined below:

- Which of these cultures impressed you most?

- Why do you think people should approach each other with tolerance (compassion)?

- What comes to your mind when culture is mentioned?

- What comes to mind when you talk about customs and habits?

- Can cultural activities contribute to peace?

Table 6. The flow chart of the lesson

\begin{tabular}{|c|c|c|c|c|c|}
\hline Step & $\begin{array}{l}\text { Dur. } \\
\text { (min.) }\end{array}$ & Teacher Behavior & Student Behavior & $\begin{array}{l}\text { Technique } \\
\text { / Method }\end{array}$ & Materials \\
\hline 01 & $\begin{array}{c}4 \\
\min .\end{array}$ & $\begin{array}{l}\text { The teacher starts the } \\
\text { lesson with a brief intro- } \\
\text { duction. }\end{array}$ & $\begin{array}{l}\text { The students introduce } \\
\text { themselves. Answer the } \\
\text { questions. }\end{array}$ & $\begin{array}{l}\text { Question } \\
\text { answer }\end{array}$ & \\
\hline 02 & $\begin{array}{c}6 \\
\text { min. }\end{array}$ & $\begin{array}{l}\text { The teacher shows im- } \\
\text { ages of different cultures } \\
\text { on the wall and asks what } \\
\text { the participants think } \\
\text { about the images. }\end{array}$ & $\begin{array}{l}\text { The students discuss the } \\
\text { images reflected on the } \\
\text { wall. }\end{array}$ & $\begin{array}{l}\text { Oral state- } \\
\text { ment }\end{array}$ & Images \\
\hline 03 & $\begin{array}{c}10 \\
\text { min. }\end{array}$ & $\begin{array}{l}\text { He asks the students to } \\
\text { hang the flash cards ac- } \\
\text { cording to the first section } \\
\text { of the instructions } \\
\text { The teacher draws the } \\
\text { clothes line in the class- } \\
\text { room. He gives those } \\
\text { in the front line } 25 \text { flash } \\
\text { cards } 25 \text { clothespins and } \\
\text { clothesline instructions } \\
\text { enough for groups of two. }\end{array}$ & $\begin{array}{l}\text { The students hang the flash } \\
\text { cards on the clothes line in } \\
\text { groups of two. } \\
\text { The students hang in } \\
\text { groups of two the flash } \\
\text { cards on the clothesline. }\end{array}$ & $\begin{array}{l}\text { Group } \\
\text { work }\end{array}$ & $\begin{array}{l}25 \text { flash } \\
\text { card, } \\
25 \text { clothes- } \\
\text { pins } \\
\text { Sufficient } \\
\text { amount of } \\
\text { clothesline } \\
\text { clothesline } \\
\text { instructions }\end{array}$ \\
\hline
\end{tabular}




\begin{tabular}{|c|c|c|c|c|c|}
\hline Step & $\begin{array}{c}\text { Dur. } \\
\text { (min.) }\end{array}$ & Teacher Behavior & Student Behavior & $\begin{array}{l}\text { Technique } \\
\text { /Method }\end{array}$ & Materials \\
\hline 04 & $\begin{array}{c}12 \\
\text { min. }\end{array}$ & $\begin{array}{l}\text { The teacher asks the } \\
\text { students to form groups } \\
\text { of seven students and } \\
\text { distributes the dialogue } \\
\text { prepared beforehand and } \\
\text { asks them to discuss the } \\
\text { contents of the dialogue } \\
\text { with the participation of } \\
\text { the referee. }\end{array}$ & $\begin{array}{l}\text { The Students constitute } \\
\text { groups of seven persons, } \\
\text { the referee distributes the } \\
\text { text of the dialogue, they } \\
\text { choose their roles, the } \\
\text { dialogues are read and its } \\
\text { contents are discussed. }\end{array}$ & $\begin{array}{l}\text { Group } \\
\text { work }\end{array}$ & $\begin{array}{l}\text { Dialogue } \\
\text { text }\end{array}$ \\
\hline 05 & $\begin{array}{c}10 \\
\text { min. }\end{array}$ & $\begin{array}{l}\text { The teacher asks the stu- } \\
\text { dents to take their places } \\
\text { in the class and asks them } \\
\text { to share the ideas related } \\
\text { to the dialogue. }\end{array}$ & $\begin{array}{l}\text { The students take their } \\
\text { places in the classroom and } \\
\text { share the ideas they have } \\
\text { made. }\end{array}$ & Class & $\begin{array}{l}\text { Individual } \\
\text { notes }\end{array}$ \\
\hline 06 & $\begin{array}{l}12 \\
\min .\end{array}$ & $\begin{array}{l}\text { The teacher announces } \\
\text { that he will be playing } \\
\text { the Word drawing game. } \\
\text { He asks the students to } \\
\text { form groups of five and } \\
\text { distributes the materials } \\
\text { prepared beforehand. }\end{array}$ & $\begin{array}{l}\text { The students thank the } \\
\text { teacher for the game and } \\
\text { form groups of five. The } \\
\text { game takes place with the } \\
\text { materials distributed. After } \\
\text { the game the students share } \\
\text { the results of the group } \\
\text { studies with the other stu- } \\
\text { dents. } \\
\text { 6a. The teacher asks the } \\
\text { students to form groups } \\
\text { of five and distributes the } \\
\text { texts written on different } \\
\text { Cultures and Tolerance and } \\
\text { asks the students to answer } \\
\text { the questions related with } \\
\text { the text. }\end{array}$ & $\begin{array}{l}\text { Group } \\
\text { work } \\
\text { and } \\
\text { presenta- } \\
\text { tion }\end{array}$ & $\begin{array}{l}\text { Materials of } \\
\text { game }\end{array}$ \\
\hline 07 & $\begin{array}{c}15 \\
\text { min. }\end{array}$ & $\begin{array}{l}\text { The teacher asks the } \\
\text { students to form groups } \\
\text { of five and distributes } \\
\text { the texts written on } \\
\text { "Different Cultures and } \\
\text { Tolerance" and asks the } \\
\text { students to answer the } \\
\text { questions related with } \\
\text { the text. }\end{array}$ & $\begin{array}{l}\text { The students form groups } \\
\text { of five and examine the } \\
\text { texts distributed and an- } \\
\text { swer the questions. }\end{array}$ & $\begin{array}{l}\text { Group } \\
\text { work }\end{array}$ & $\begin{array}{l}\text { Reading } \\
\text { text } \\
\text { answer } \\
\text { sheet }\end{array}$ \\
\hline 08 & $\begin{array}{c}8 \\
\min .\end{array}$ & $\begin{array}{l}\text { According to the second } \\
\text { section of the instructions } \\
\text { the teacher asks the flash } \\
\text { cards, clothespins and the } \\
\text { clothesline to be collected } \\
\text { and given to the class } \\
\text { leader. }\end{array}$ & $\begin{array}{l}\text { The students give the flash } \\
\text { cards, clothespins and } \\
\text { the clothesline to the class } \\
\text { leader. }\end{array}$ & $\begin{array}{l}\text { Individual } \\
\text { work }\end{array}$ & $\begin{array}{l}25 \text { flash } \\
\text { cards, } \\
25 \text { clothes- } \\
\text { pins suf- } \\
\text { ficient } \\
\text { number of } \\
\text { clotheslines } \\
\text { instructions }\end{array}$ \\
\hline
\end{tabular}


Journal of Education Culture and Society No. 1_2018

\begin{tabular}{|c|c|c|c|c|c|}
\hline Step & $\begin{array}{c}\text { Dur. } \\
\text { (min.) }\end{array}$ & Teacher Behavior & Student Behavior & $\begin{array}{l}\text { Technique } \\
\text { / Method }\end{array}$ & Materials \\
\hline 09 & $\begin{array}{c}3 \\
\min .\end{array}$ & $\begin{array}{l}\text { The teacher summarizes } \\
\text { the activity, thanks the } \\
\text { participants and assigns } \\
\text { them homework for the } \\
\text { next lesson. }\end{array}$ & $\begin{array}{l}\text { The students take notes } \\
\text { while listening to the teach- } \\
\text { er. They thank the teacher } \\
\text { for the activity. }\end{array}$ & $\begin{array}{l}\text { Oral state- } \\
\text { ment }\end{array}$ & \\
\hline \multicolumn{6}{|c|}{ Total period: 80 minutes } \\
\hline
\end{tabular}

Task:

1. Express your opinions in 2 pages (approximately in 400 words) about the chart below.

2. Then prepare a similar table for the model of peace.

3. Share the work you prepared with the class.

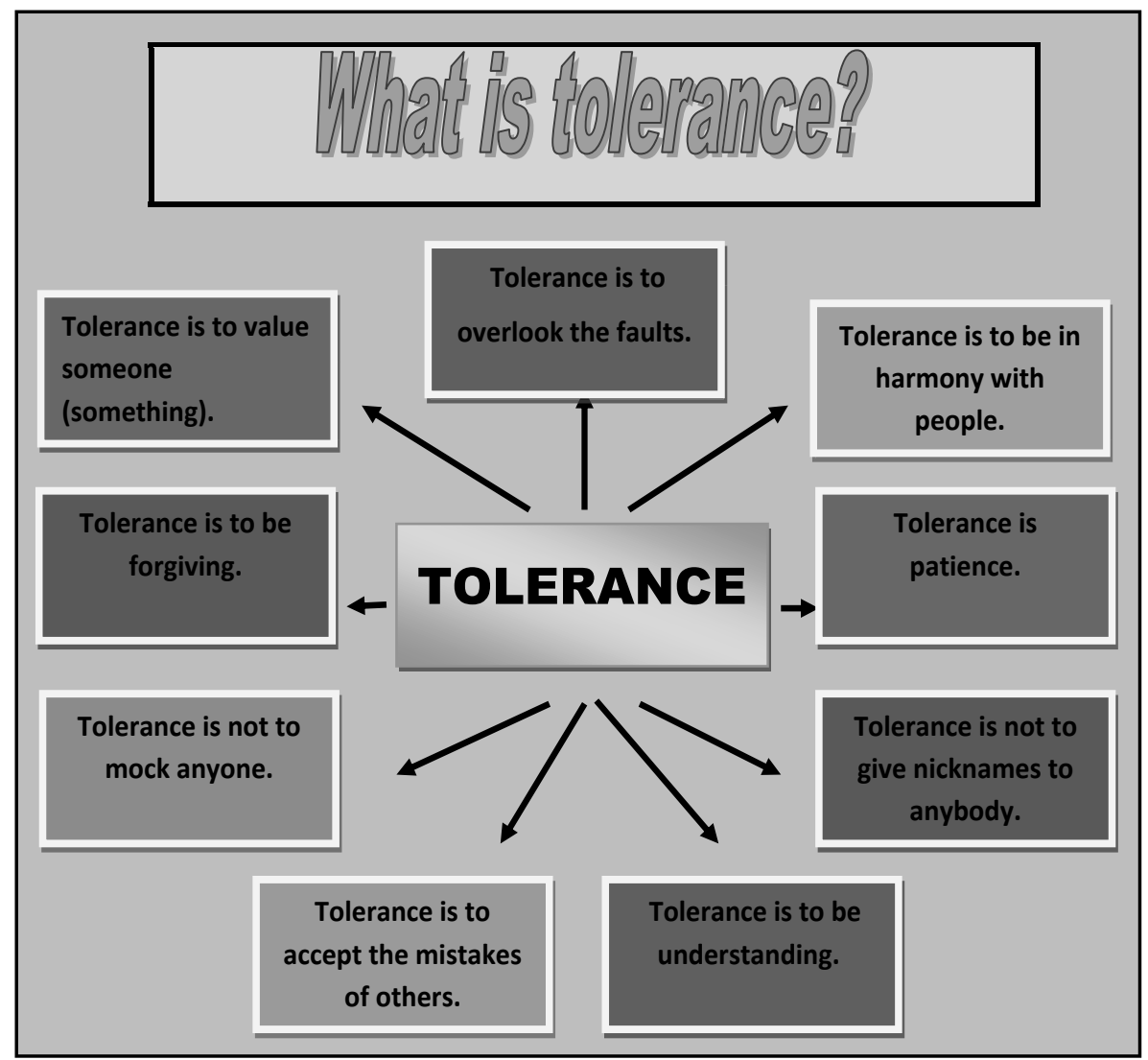

Figure 1. Mind map for tolerance

Source: Talipyener.meb.k12.tr, Retrieved: December 2, 2017. 


\section{EVALUATION}

One of the most important stages in the planning of educational activities is evaluation. Evaluation is conducted to measure how close the envisioned targets have been reached (Bakırcığlu, 2016, p. 434; Başol, 2016, p. 3). Together with the teaching and learning process, evaluation of the materials used is also important. Therefore, evaluation covers the studies done prior to the realization of the activity and the teaching and learning process. The results of evaluation provide feedback to the individual who plans the teaching and learning process. Therefore, during the planning stage, the lesson to be evaluated needs to be planned in detail and the necessary measuring and evaluation tools should be carefully prepared (Bayçu, Kocadă̆, \& Coşkun, 2014, pp.24).

The teachers are requested to write an essay of approximately 150 words on evaluation. Later, the written answers given in the dialogue and in the reading texts are analyzed. An Observation and Evaluation Form comprised of ten topics are used for the teacher to evaluate the activity from his/her perspective. Given below is the Observation and Evaluation Form prepared for the subject of peace.

Table 7. Observation and evaluation form

\begin{tabular}{|c|c|c|c|c|c|c|}
\hline \multirow[t]{2}{*}{ No } & \multirow[t]{2}{*}{ Skills } & \multicolumn{5}{|c|}{ Degrees of Evaluation } \\
\hline & & Poor & Passing & Medium & Good & Excellent \\
\hline 01 & $\begin{array}{l}\text { Was there effective participation by } \\
\text { the participants? }\end{array}$ & & & & & \\
\hline 02 & $\begin{array}{l}\text { Was there sufficient discussion on } \\
\text { the subject by the participants? }\end{array}$ & & & & & \\
\hline 03 & $\begin{array}{l}\text { Was there concrete explanation } \\
\text { about cultural differences? }\end{array}$ & & & & & \\
\hline 04 & $\begin{array}{l}\text { Was the subject of cultural differ- } \\
\text { ences understood? }\end{array}$ & & & & & \\
\hline 05 & $\begin{array}{l}\text { Was the model of tolerance under- } \\
\text { stood? }\end{array}$ & & & & & \\
\hline 06 & $\begin{array}{l}\text { Were the necessary messages deliv- } \\
\text { ered in the intended places? }\end{array}$ & & & & & \\
\hline 07 & $\begin{array}{l}\text { Were the participants able to estab- } \\
\text { lish a connection between culture } \\
\text { and tolerance at the end of the les- } \\
\text { son? }\end{array}$ & & & & & \\
\hline 08 & $\begin{array}{l}\text { Were different cultures discussed } \\
\text { sufficiently? }\end{array}$ & & & & & \\
\hline 09 & $\begin{array}{l}\text { Were you able to attract the atten- } \\
\text { tion of the participants in the lesson? }\end{array}$ & & & & & \\
\hline 10 & $\begin{array}{l}\text { Was the productivity, expected } \\
\text { from the lesson, achieved? }\end{array}$ & & & & & \\
\hline
\end{tabular}

Source: Author. 


\section{CONCLUSION AND RECOMMENDATIONS}

Every year millions of people migrate from one country to another. This situation causes an influx of migration in some countries. Keeping the problems to a minimum level is contingent on the achievement of the peace environment and its continuation. Opportunities for individuals from different cultures to live together should be achieved in a country. Knowledge of cultures and tolerance plays the biggest role in achieving this. Therefore, culture and models of tolerance should be taught in educational institutions. The difference in cultures should be explained. Thus, the groups will get to know one another better and see the similarities and the differences in each other. The basis of tolerance is to see the differences and to accept these. At the same time, benefits should be derived from the similarities. Humans live in a society and interact with other individuals. The important thing here is the attitude of one person towards others (Demirezen, 2017, pp. 223).

Turkey has a multi-cultural society. In other words, there is no single ethnic group, religion, language, sect, culture and similar values. There is a different cultural structure. Our society has emphasized this feature in our Constitution. This structure in our country and extends to our neighboring countries. This migration started in 1960, and has enriched this multi-lingual, multi-cultural and multi-religious structure of the country. It is estimated that $10 \%$ of Turkish nationals live abroad in 35 countries.

One needs to acknowledge that individuals are members of different groups who are individuals in their groups and to respect them according to their values and cultures. In general, no matter what the opinion of the individual may be s/ he should have the liberty (freedom) to form his culture and express his views. Every individual has his/her own unique system of values, judgments and opinions. Being tolerant to individuals who think differently and to respect them and to have positive attitude towards them is a sign of tolerance. This difference should not affect the individual and the others in a negative manner. Ataturk's slogan "Peace at Home and Peace in the World" should be emphasized in the teaching of peace education. In our times, World War 111 is inescapably impending, which must be stopped. Therefore, Demirezen declares (2017, p. 230), "the only power to prevent a world War 111 is peace education".

I would like to reiterate that 1 have used this model successfully in Turkish and German lessons. According to my observations, the said model may be used in lessons attended by the immigrants in English and other languages also.

\section{RECOMMENDATIONS FOR PEACE EDUCATION:}

- We must create an atmosphere of peace as a society.

- We must be tolerant towards different cultures.

- We must recognize the different culture.

- We must take the similarities of the cultures as the basis in education.

- We should empathize with each other rather than look for differences. 
- As a tolerant society we should not criticize one other for the differences and cause problems but should respect one another.

- The individual should be made aware that tolerance has limitations.

- We should include education on peace in the training programs of teachers

- Coordination should be established between the agencies and organizations working in the field of peace education..

- Information and experiences gained on peace education should be shared with all concerned.

- We should not use the studies conducted on peace education for political reasons.

- We should take the developments on peace in South America as an example.

- We should support the student and teacher exchange programs.

- We should support inter-cultural education activities.

- We should compare what the revisions say about peace and research for educational purposes.

- We should trace peace education as interdisciplinary subjects in the educational institutions.

- We can implement these proposals only with a political agenda that promotes peace.

\section{REFERENCES}

1. Bakırcıŏlu, R. (2016). Ansiklopedik Eğitim ve Psikoloji Sözlüğü. [Encyclopedic Dictionary of Education and Psychology], Genişletilmiş 2. Baskı, Ankara: Anı Yayıncılık.

2. Başol, G. (2016). Eğitimde Ölçme ve Değerlendirme [Measurement and Evaluation in Education]. Ankara: Pegem Akademi.

3. Bayçu, S., Kocadă̆, T., \& Coşkun, H. (2014). Masalların Dil Öğretiminde Kullanımı [Use of fairy tales in language teaching]. In: H. Coşkun (Ed.), Eğitim ve Öğretimde Masalların Önemi -Planlama, Uygulama ve Değerlendirme [The Importance of Fairy Tales in Education - Planning, Practising and Evaluating], (pp. 15-32). Berlin: Dagyeli Verlag.

4. Coşkun, H. (2017). Barış Eğitimi / Friedenspädagogik / Peace Education. Berlin: Friedrich-EbertStiftung \& Dagyeli Verlag.

5. Demirezen, M. (2017). Why Peace Education is a must? In: H. Coşkun (Ed.). Barış Eğitimi / Friedenspädagogik / Peace Education (pp. 121-132). Berlin: Friedrich-Ebert- Stiftung \& Dagyeli Verlag.

6. Grosser, A. (2017). Le Mensch, die Ethik der Identitäten [Man, the ethics of identities]. Bonn: Dietz.

7. Meyer, L. (1978). Traininsprogramm zur Lernzielanalyse [Training Programme for learning objective analysis]. Erziehungswissenschaft, Autenäum Taşenbücher: Königstein/ Ts.

8. Püsküllüoğlu, A. (1995). Türkçe Sözlük [Turkish Dictionary]. İstanbul: Yapı Kredi Yayınları.

9. Şahbenderoğlu, V. (2010). Yaşamak Şakaya Gelmez: Barış İ̧̧in Hoşgörü. [Life does not joke with itself: Tolerance for peace]. Sayı:19/Y1l 5 Haziran/2010, Ankara: Atılım Üniversitesi.

10. Taştekin, F. (2017). Trump'ın Kudüs kararı: Orta Doğu'da barışı öldürmek için mükemmel zamanlama [Trump's decision on Jerusalem: Perfect timing for the destruction of peace in the Middle East]. Retrieved December 25, 2017, from: http://www.bbc.com/turkce/ haberler-dunya42261350.

11. Zammit, J., \& Hagel, S. (Ed.). (2015). Learning for Peace, A guide to developing outstanding SMSC in your primary school, Birmingham: Lifeworlds Learning CIC peacemakers. 


\section{ILLUSTRATIONS}

1. [Titled illustration of a mind map for tolerance]. Retrieved May 2, 2017 from http://talipyener.meb.k12.tr/icerikler/degerler-egitimi_1757203.html

2. [Untitled illustration of tolerance]. Retrieved July 26, 2017 from https://www.psychologytoday. com/us/blog/looking-in-the-cultural-mirror/201402/tolerance-acceptance-understanding

3. [Untitled illustration of peace]. Retrieved May 25, 2017 from https://www.pakistantoday. com.pk/2013/09/21/national-youth-peace-festival-from-26th/.

4. [Untitled illustration of community / unity]. Retrieved January 24, 2018 from http:/ / www.timetoplay.com/2016/12/30/what-do-our-people-need-a-sense-of-community-and-belonging/.

5. [Untitled illustration of divided]. Retrieved May 31, 2017 from https://www.istockphoto. com/tr/foto\%C4\%9Fraf/atom-3d-gm533925818-94638627

6. [Untitled illustration of conflict]. Retrieved January 27, 2018 from https://psychology20. wikispaces.com/06.+Conflict+Resolution.

7. [Untitled illustration of a child]. Retrieved May 3, 2017 from https://www.malvorlagenkostenlos.com/ausmalbilder-gratis/baby-ausmalbilder-gratis/kinderbilder-zum-ausdrucken-kostenlos-3038.html.

8. [Untitled illustration of religion]. Retrieved May 31, 2017 from https://religion.illinois.edu/.

9. [Untitled illustration of hostility]. Retrieved May 31, 2017 from https://library.wlu.ca/ locations/brantford.

10. [Untitled illustration of empathy]. Retrieved May 4, 2017 from http://www.dmy.info/ empati-nedir/.

11. [Untitled illustration of diversity]. Retrieved May 3, 2017 from https://www.ohio.edu/ diversity/.

12. [Untitled illustration of trust]. Retrieved May 4, 2017 from https://pixabay.com/tr/ kalp-i\%C3\%A7in-anahtar-a\%C5\%9Fk-kale-sembol-3404116/.

13. [Untitled illustration of a dove]. Retrieved May 3, 2017 from http://www.anatoliamed.com

14. [Untitled illustration of migration]. Retrieved May 31, 2017 from http://www.maggieblanck.com/Immigration.html.

15. [Untitled illustration of sensibility]. Retrieved May 4, 2017 from http://blog.milliyet.com.tr/ toplumsal-duyarlilik/Blog/?BlogNo=25952.

16. [Untitled illustration of life]. Retrieved May 4, 2017 from http://galeri.uludagsozluk.com/r/ hayat-492485/.

17. [Untitled illustration of to explore]. Retrieved May 31, 2017 from https://www.4teachers. $\mathrm{de} /$ ?action=keywordsearch\&searchtype=images\&searchstring=Lupe.

18. [Untitled illustration of culture]. Retrieved May 3, 2017 from https://thenounproject.com/ term/arts-and-culture/13644/.

19. [Untitled illustration of happiness]. Retrieved May 4, 2017 from http:/ / www.erkeklerinprensesi.net/bu-mutluluk-duasi-harika-etkili-asla-kacirmayin/.

20. [Untitled illustration of refugee]. Retrieved May 31, 2017 from http://hasanferruhozgen meb.k12.tr/icerikler/hasan-ferruh-ozgen-anadolu-lisesi-quotmulteciquot-konulu-resimyarismasi_3816386.html.

21. [Untitled illustration of prosperity]. Retrieved May 31, 2017 from https://tr.123rf.com/stock-photo/prosperity.html?sti=nlzjldvvhthepvsh5e |

22. [Untitled illustration of attack]. Retrieved May 31, 2017 from https://www.shareicon.net/.

23. [Untitled illustration of war]. Retrieved May 25, 217 from http://nations.wikia.com/wiki/ Korean_War

24. [Untitled illustration of love]. Retrieved May 4, 2017 from http://www.derszamani.net/ sevgi-kavraminin-sizin-icin-anlami-nedir.html.

25. [Untitled illustration of food culture]. Retrieved May 4, 2017 from http://www.sermelex. com/Recipes.aspx?Trf=Pide.

26. [Untitled illustration of olive-branch]. Retrieved May 3, 2017 from https://www.uludagsozluk.com/k/zeytin-dal\%C4\%B1/. 


\section{ANNEX 1}

Answers to the questions on dialogue text

1. Empathy is the notion of putting oneself in the place of the person and trying to understand his/her feelings and thoughts.

2. It affects children and women the most.

3. The most effective model in the solution of the problems created by different cultures is empathy.

4. Mevlana is the first name that comes to mind in mysticism as an example of tolerance.

5. Tolerance is to ignore mistakes and differences. This enables individuals from different cultures to live together in harmony.

\section{ANNEX 2}

Answers to the questions of the reading text

1. Tolerance is not to oppose but to listen and respect the opinions of the person speaking even though it may be totally contrary to your opinion.

2. We learn tolerance from our families and our environment.

3. Yes, every society has its own culture.

4. We call people who escape from the war and take refuge in another country as refugees.

5. The basic right of human rights is the right to live.

\section{ANNEX 3}

A Student Sample from German Courses

Ad1 ve soyad1 Liste Sıra Numarası : .... Tarih: 9.1.2018

Notu: ...

Vor- und Nachname:

Listen-Reihennummer: .... Datum:

Note:

Name and Surname :

List-Range Number $\quad$.... Date :

Note: ....

Etkinlikte (Derste) Kullanılan Anahtar Sözcük ve 24 Sözcük

Flaş Kart / Lernkarte / Flash Card 


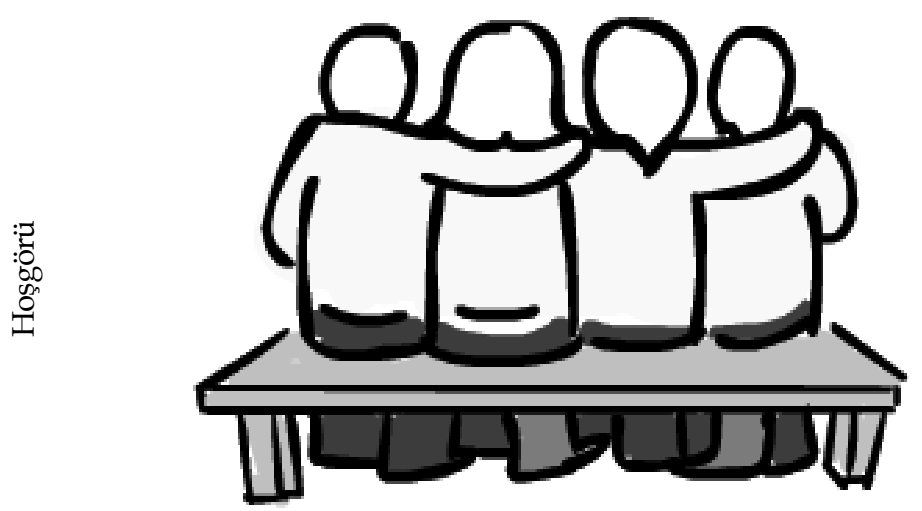

\section{$\mathrm{OO}$}

Bu resim ile ilgili 5 Türkçe, Almanca ve İngilizce cümle yazınız. (beş sözcük)

Schreiben Sie über dieses Bild 5 Sätze auf Türkisch, Deutsch und Englisch. (fünf Wörter) Write down 5 sentences about this picture in Turkish, German and English. (five words)

\begin{tabular}{|c|c|c|c|}
\hline No & Türkçe & Deutsch & English \\
\hline 01 & $\begin{array}{l}\text { Irkçılık hayatta sonradan } \\
\text { ögrrenilir. }\end{array}$ & $\begin{array}{l}\text { Rassismus wird im } \\
\text { Leben später gelernt. }\end{array}$ & $\begin{array}{l}\text { Racism is learned later } \\
\text { in life. }\end{array}$ \\
\hline 02 & $\begin{array}{l}\text { Sarışın çocuk kıza çıçek } \\
\text { hediye ediyor. }\end{array}$ & $\begin{array}{l}\text { Der blonde Junge schenkt } \\
\text { dem Mädchen eine } \\
\text { Blume. }\end{array}$ & $\begin{array}{l}\text { The blonde child gives } \\
\text { a flower to the girl as a } \\
\text { gift. }\end{array}$ \\
\hline 03 & $\begin{array}{l}\text { Çocuklar ağaçların } \\
\text { arkasında oynuyorlar. }\end{array}$ & $\begin{array}{l}\text { Die Kinder spielen hinter } \\
\text { den Bäumen. }\end{array}$ & $\begin{array}{l}\text { The children are playing } \\
\text { behind the trees. }\end{array}$ \\
\hline 04 & $\begin{array}{l}\text { Çocuklar birbirlerine } \\
\text { insancil davraniyorlar. }\end{array}$ & $\begin{array}{l}\text { Die Kinder sind } \\
\text { freundlich zueinander. }\end{array}$ & The kids are friendly. \\
\hline 05 & Kız mutlu gözükmüyor. & $\begin{array}{l}\text { Das Mädchen sieht nicht } \\
\text { glücklich aus. }\end{array}$ & $\begin{array}{l}\text { The little girl does not } \\
\text { look happy. }\end{array}$ \\
\hline
\end{tabular}

Source: Psychologytoday.com, retrieved July 26, 2017

\section{ANNEX 4}

First Group of Sentences

Tablodaki sözcüklerle birer cümle yazınız. (Bir cümlede 5 sözcük)

Schreiben Sie mit den Wörtern in der Tabelle jeweils einen Satz . (in einem Satz 5 Wörter)

Write one sentence for each word in the list. (five words in one sentence)

Sözcük Listesi / Wortliste / Word List / Höşgörü / die Toleranz / The Tolerance (a) 


\begin{tabular}{|c|c|c|c|}
\hline Nr. & $\begin{array}{l}\text { Resim/Bild/ } \\
\text { Picture }\end{array}$ & $\begin{array}{l}\text { Sözcük / Wort / } \\
\text { Word }\end{array}$ & Cümle/Satz/Sentence \\
\hline \multirow{3}{*}{01} & & bariş & Dünyada barış yok. \\
\hline & & der Frieden & Auf der Erde ist kein Frieden. \\
\hline & & peace & There is no peace in the world. \\
\hline \multirow{3}{*}{02} & & birlik & Birlikten güç doğar. \\
\hline & & $\begin{array}{l}\text { die } \\
\text { Gemeinschaft }\end{array}$ & Aus der Gemeinschaft kommt Kraft. \\
\hline & & $\begin{array}{l}\text { community } \\
\text { (unity) }\end{array}$ & Power comes from community. \\
\hline \multirow{3}{*}{03} & & bölünmek & Türk toplumu bölünmüştür. \\
\hline & & geteilt sein & Die türkische Gesellschaft ist geteilt. \\
\hline & & divided & The community in the Turkey is divided. \\
\hline \multirow{3}{*}{04} & & çatışma & Çatışma en kısa sürede çözülmelidir. \\
\hline & & der Konflikt & $\begin{array}{l}\text { Der Konflikt sollte so schnell wie möglich } \\
\text { gelöst werden. }\end{array}$ \\
\hline & & conflict & $\begin{array}{l}\text { The conflict should be solved as soon as } \\
\text { possible. }\end{array}$ \\
\hline \multirow{3}{*}{05} & & çocuk & Büyükbabam çocukları sevmez. \\
\hline & & das Kind & Mein Großvater kann Kinder nicht leiden. \\
\hline & & child & My grandfather doesn't like children. \\
\hline \multirow{3}{*}{06} & & din & Dinim benim için önemlidir. \\
\hline & & die Religion & Meine Religion ist wichtig für mich. \\
\hline & & religion & My religion is important to me. \\
\hline \multirow{3}{*}{07} & & düşmanlık & Düşmanlık insanlığa zarar vermektedir. \\
\hline & & $\begin{array}{l}\text { die } \\
\text { Feindseligkeit }\end{array}$ & Die Feinseligkeit schadet der Menschheit. \\
\hline & & hostility & Hostility harms humanity. \\
\hline \multirow{3}{*}{08} & \multirow{3}{*}{$\left.\right|_{0}$} & empati & $\begin{array}{l}\text { İnsan ve hayvan arasındaki empati } \\
\text { önemlidir. }\end{array}$ \\
\hline & & die Empathie & $\begin{array}{l}\text { Die Empathie zwischen Mensch und Tier } \\
\text { ist wichtig. }\end{array}$ \\
\hline & & empathy & $\begin{array}{l}\text { The empathy between human beings and } \\
\text { animals is important. }\end{array}$ \\
\hline \multirow{3}{*}{09} & & farklılik & İnsanlar arasındaki farklılık muazzamdır. \\
\hline & & die Vielfalt & $\begin{array}{l}\text { Die Vielfalt zwischen Menschen ist } \\
\text { erstaunlich. }\end{array}$ \\
\hline & & diversity & The diversity between humans is incredible. \\
\hline
\end{tabular}




\begin{tabular}{lll}
\hline güven & \begin{tabular}{l} 
Toplumda güven oldukça önemlidir. \\
\hline das Vertrauen
\end{tabular} & $\begin{array}{l}\text { Das Vertrauen ist sehr wichtig in der } \\
\text { Gemeinschaft. }\end{array}$ \\
\hline
\end{tabular}

\section{ANNEX 5}

Second Group of Sentences

Tablodaki sözcüklerle birer cümle yazınız. (Bir cümlede 5 sözcük)

Schreiben Sie mit den Wörtern in der Tabelle jeweils einen Satz. (in einem Satz 5 Wörter)

Write one sentence for each word in the table. (five words in one sentence)

Sözcük Listesi / Wortliste / Word List / Hoşgörü / dieToleranz / The Tolerance (b)

\begin{tabular}{|c|c|c|c|}
\hline & $\begin{array}{l}\text { Resim / Bild / } \\
\text { Picture }\end{array}$ & $\begin{array}{l}\text { Sözcük / Wort } \\
\text { / Word }\end{array}$ & Cümle / Satz / Sentence \\
\hline \multirow{3}{*}{13} & & hassasiyet & Kadınların hassasiyeti daha yüksektir. \\
\hline & & die Sensibilität & Frauen haben eine höhere Sensibilität. \\
\hline & & sensibility & Women have a higher sensibility. \\
\hline \multirow{3}{*}{14} & & hayat & Afrika'da hayat zordur. \\
\hline & & das Leben & Das Leben in Afrika ist schwer. \\
\hline & & life & Life in Africa is hard. \\
\hline \multirow{3}{*}{15} & & keşfetmek & $\begin{array}{l}\text { Her gün yeni şeyler keşfetmek sizi hayatta } \\
\text { tutar. }\end{array}$ \\
\hline & & erkunden & $\begin{array}{l}\text { Sich jeden Tag über neue Sachen } \\
\text { erkunden, halt Sie lebendig. }\end{array}$ \\
\hline & & to explore & $\begin{array}{l}\text { To explore new things every day keeps } \\
\text { you alive. }\end{array}$ \\
\hline \multirow{3}{*}{16} & & kültür & Kültürün karmaşık bir yapısı vardır. \\
\hline & & die Kultur & Die Kultur hat eine komplexe Struktur. \\
\hline & & culture & Culture has a complex structure. \\
\hline
\end{tabular}




\begin{tabular}{|c|c|c|}
\hline \multirow{3}{*}{17} & mutluluk & Bazı insanlar çok şanslıdırlar. \\
\hline & das Glück & Manche Menschen haben viel Glück. \\
\hline & luck & Some people have a lot of luck. \\
\hline \multirow{3}{*}{18} & mülteci & Mülteci hayatta kalmaya çalışıyor. \\
\hline & der Flüchtling & Der Flüchtling versucht zu überleben. \\
\hline & refugee & The refugee tries to survive. \\
\hline \multirow{3}{*}{19} & refah & Refah her ülkede farklıdır. \\
\hline & der Wohlstand & $\begin{array}{l}\text { Wohlstand ist in jedem Land } \\
\text { unterschiedlich. }\end{array}$ \\
\hline & prosperity & Prosperity differs in each country. \\
\hline \multirow{3}{*}{20} & saldirı & Hırsızın saldırısı oldukça \\
\hline & der Angriff & $\begin{array}{l}\text { Der Angriff von dem Räuber war sehr } \\
\text { schnell. }\end{array}$ \\
\hline & attack & The attack of the thief was really quick. \\
\hline \multirow{3}{*}{21} & savaş & İsrail ile Filistin arasındaki savaş haksızdır. \\
\hline & der Krieg & $\begin{array}{l}\text { Der Krieg zwischen den Palästina und } \\
\text { Israel ist unfair. }\end{array}$ \\
\hline & war & $\begin{array}{l}\text { The war between Palestine and Israel is } \\
\text { unfair. }\end{array}$ \\
\hline \multirow{3}{*}{22} & sevgi & $\begin{array}{l}\text { Babam ile benim aramdaki sevgi } \\
\text { muhteşem. }\end{array}$ \\
\hline & die Liebe & $\begin{array}{l}\text { Die Liebe zwischen mir und meinem Vater } \\
\text { ist entzückend. (prächtig) }\end{array}$ \\
\hline & love & $\begin{array}{l}\text { The love between me and my father is } \\
\text { amazing. }\end{array}$ \\
\hline \multirow{3}{*}{23} & yemek kültürü & $\begin{array}{l}\text { İtalya'nın yemek kültürünü çok } \\
\text { beğeniyorum. }\end{array}$ \\
\hline & die Esskultur & Die Esskultur von Italien gefällt mir sehr. \\
\hline & food culture & I like the food culture of Italy very much. \\
\hline \multirow{3}{*}{24} & zeytin dalı & $\begin{array}{l}\text { Zeytin dalı uluslararası barışın } \\
\text { sembolüdür. }\end{array}$ \\
\hline & $\begin{array}{l}\text { der } \\
\text { Olivenzweig }\end{array}$ & $\begin{array}{l}\text { Der Olivenzweig ist ein internationales } \\
\text { Symbol. }\end{array}$ \\
\hline & olive-branch & $\begin{array}{l}\text { The olive-branch is an international symbol } \\
\text { standing for peace. }\end{array}$ \\
\hline
\end{tabular}

I have developed this lesson model. The following students have worked on this lesson draft. In addition, two contributors provided me feedback in the final draft.

Contributors: Şule Demirci, Fatma Nur Küççük, Teslime Yaşar, Yeşim Çelikbaş, Aziz Kurçak, Afife Işık, Julia Goggin 